\title{
Przedsiębiorczość a innowacyjność - rozumienie i delimitacja pojęć
}

DOI: $10.47050 / 65591760.50-63$

Piotr Kopyciński

Celem niniejszego rozdziału jest dokonanie delimitacji używanych czasami synonimicznie pojęć „przedsiębiorczość” oraz „innowacyjność”. Dla zrealizowania tego zamierzenia wskazano na rozumienie tych sformułowań, a także wyrażeń pokrewnych („przedsiębiorca” i „innowacja”). Wśród różnych ujęć przedsiębiorczości skoncentrowano się na tym mającym powiązanie z innowacyjnością.

\section{Słowa kluczowe:}

przedsiębiorczość

innowacje

innowacyjność 


\section{Entrepreneurship and innovation \\ - understanding and \\ delimitation of concepts}

DOI: $10.47050 / 65591760.50-63$

Piotr Kopyciński

The aim of this chapter is to delimit concepts of „entrepreneurship" and „innovation". In order to achieve this intention, it was pointed out understanding of these formulations. Among the various approaches of "entrepreneurship", the focus has been on those connected with innovation.

Keywords:

entrepreneurship

innovation

innovativeness 


\section{Wstęp}

Znaczenie wyrażeń "przedsiębiorczość" oraz „innowacyjność" ewoluowało w ostatnich latach. Współcześnie pojęć tych używa się w różnych kontekstach i często traktowane są synonimicznie. $Z$ tego względu zasadne jest przybliżenie czytelnikowi różnych znaczeń tych słów, a także zaproponowanie delimitacji, która pozwoli na ich rozróżnienie na potrzeby tematyki przedstawionej w niniejszej monografii. W związku z tym, że problematyce przedsiębiorczości poświęcona jest cała publikacja, w tym tekście pojęcie to będzie omawiane jedynie w zakresie niezbędnym do wspomnianego rozgraniczenia z pojęciem "innowacyjność". Kluczowe będzie za to przedstawienie istoty tej ostatniej.

\section{Rozumienie przedsiębiorczości}

Uściślając prezentowany tok rozumowania, z tytułową kategorią możemy łączyć dwa pojęcia: przedsiębiorczość jako określoną czynność/proces oraz przedsiębiorcę jako osobę realizującą stosowne działania związane z zakładaniem działalności / funkcjonowaniem firmy ${ }^{1}$.

Przedsiębiorczość może być rozumiana jako zdolność i gotowość do rozwijania, organizowania i zarządzania przedsiębiorstwem, uwzględniając wszelkie związane z tym ryzyka, w celu osiągnięcia zysku (Business Dictionary 2018). Z kolei przedsiębiorcą będzie osoba podejmująca tego typu działania. Wśród wielu autorów ten sposób rozumowania potwierdza T. Oleksyn (2012). Wskazuje on, że „przedsiębiorca to człowiek, który jest jednocześnie założycielem firmy, osobiście nią zarządza i sam ponosi pełne ryzyko i odpowiedzialność finansową, związane z jej prowadzaniem" (Oleksyn 2012, s. 11). Przedsiębiorca szuka więc szans na biznes, ponosząc stosowne ryzyko finansowe, ale niekoniecznie samodzielnie tworzy te szanse.

Natomiast w innym podejściu za przedsiębiorcę uważa się jednostkę, która posiada umiejętność znajdowania i wykorzystywania możliwości oraz przekuwania pomysłów na nowe produkty. W takim ujęciu przedsiębiorca potrafi rozpoznać komercyjny potencjał danego produktu, a także, przy wykorzystaniu talentu i kapitału, zamienić inwencję w innowację. W tym podejściu pojęcie "przedsiębiorczość" obejmuje tak- 
że aktywność innowacyjną zarówno istniejących, jak i powstających przedsiębiorstw (Audretsch i in. 2002).

Z powyższego można więc wnioskować, że omawiane sformułowania nie są jednoznaczne. Jak można zauważyć, w pierwszym z przedstawianych podejść na główny plan wysuwa się łączenie pojęć „przedsiębiorca" i „przedsiębiorczość" z zarządzaniem firmą. W takim ujęciu w przedsiębiorstwie mogą powstawać innowacje, ale projektującym zmiany niekoniecznie będzie tak rozumiany przedsiębiorca. W drugim zaś podejściu pojęcia te wiążą się bezpośrednio z innowacyjnością. Przyjmując, z racji tematyki niniejszego tekstu, tę drugą optykę, można mówić o trzech podejściach do przedsiębiorczości (Bal-Woźniak 2007):

1. Przedsiębiorczość w kontekście znaczenia przedsiębiorcy w rozwoju społeczno-gospodarczym.

2. Analiza natury przedsiębiorczości i składowych jej struktury wewnętrznej.

3. Upowszechnianie przedsiębiorczości opartej na innowacyjności.

Z perspektywy rozważań w niniejszym artykule szczególnie istotne jest to ostatnie podejście. Przedsiębiorczość oparta na wiedzy, wykorzystująca takie narzędzia jak innowacje i innowacyjności, jest współcześnie niezbędnym czynnikiem sukcesu firm (Bal-Woźniak 2007). W takim ujęciu można powiedzieć, że nie ma przedsiębiorczości bez innowacyjności.

W tym kontekście należy odwołać się do dorobku jednego z prekursorów rozważań na temat innowacyjności - J. Schumpetera. Widzi on ścisłe powiązanie pomiędzy tą problematyką a przedsiębiorczością. Jak wskazuje, przy powstawaniu „nowych kombinacji” środków produkcji (jak nazywał wówczas innowacje) kluczowe znaczenie ma przedsiębiorca, którego pomysłowość, siła perswazji i wola pozwalają zorganizować nowe przedsiębiorstwo i przeprowadzić innowację: „Czynnikiem konstytuującym przedsiębiorcę jest realizowanie nowych kombinacji" (Schumpeter 1960, s. 118).

Na podstawie powyższych rozważań możemy wskazać dwa podejścia do problematyki przedsiębiorczości, z których w pierwszym na główny plan wysuwają się zagadnienia zarządzania firmą, a w drugim kwestie związków między omawianą kategorią a innowacyjnością. Skoro w niniejszej pracy przyjęto, że szczególnie istotny jest ten drugi związek, to powstaje pytanie o rozumienie innowacyjności. Przyjrzyjmy się zatem bliżej tej problematyce. 


\section{Rozumienie innowacyjności}

Na wstępie warto podkreślić, że często można spotkać się z zamiennym używaniem pojęć „innowacja” i „innowacyjność". Ich znaczenie jest jednak różne. Zdefiniowanie innowacyjności jest stosunkowo proste - można ją rozumieć jako zdolność określonych podmiotów do wdrażania nowych pomysłów. Sprawa komplikuje się przy doprecyzowywaniu pojęcia „innowacja”. W tym przypadku, oprócz różnych szczegółowych klasyfikacji, istotne są dwa podejścia. W pierwszym, nazwijmy je klasycznym, innowacje są traktowane jako indywidualny problem przedsiębiorcy (przedsiębiorstwa). To zadaniem firmy jest wymyślić, zaprojektować, przetestować i wdrożyć stosowne rozwiązanie na rynku. Mogą to być innowacje technologiczne (produktowe i procesowe) lub nietechnologiczne (organizacyjne i marketingowe). W drugim zaś ujęciu, które pojawiło się stosunkowo niedawno, zwraca się uwagę na społeczny (kolektywny) wymiar powstawania nowych rozwiązań. Drugoplanowy zaś staje się rodzaj wdrażanej innowacji. W tym podejściu innowacje powstają w ramach interakcji różnych osób i podmiotów, wychodząc naprzeciw oczekiwaniom określonych grup. Pojawia się tu cały katalog podejść. Mówimy o innowacjach społecznych (np. Murray, Caulier-Grice, Mulgan 2010; BEPA 2011) i ich szczególnym przypadku - innowacjach miejskich (Kopyciński 2018), podkreślamy powstawanie innowacji we współpracy z szerokim spektrum aktorów (open innovation, por. Chesbrough, Vanhaverbeke, West 2006) czy wręcz przy udziale przyszłych użytkowników w tworzeniu rozwiązań spełniających ich oczekiwania (user innovation, democratizing innovation - por. E. von Hippel 2005; living labs - np. World Bank 2014, collaborative innovation - np. J. Torfing 2016). Możemy więc mówić o ewolucji rozumienia innowacji od ujęcia stricte technologicznego w kierunku rozumienia społecznego, gdzie znaczenia nabierają takie procesy jak: kooperacja, współtworzenie (co-creation), wzajemne uczenie się czy współdzielenie (co-sharing).

Należy przy tym podkreślić, że dwa prezentowane wyżej podejścia wzajemnie się nie wykluczają, są to po prostu dwie perspektywy badań nad innowacjami. Możemy więc przykładowo mówić o innowacji produktowej powstałej w wyniku interakcji/zapotrzebowania społecznego (swoista "społeczna innowacja produktowa"). Aby szerzej zrozumieć te zawiłości, przyjrzyjmy się szczegółowo klasyfikacji innowacji.

Wśród współczesnych propozycji rozumienia pojęcia „innowacja” z pewnością ważne jest ujęcie zaproponowane na początku XX w. przez 
J. Schumpetera. Według tego autora innowacja to nowa kombinacja środków produkcji obejmująca:

„1. Wprowadzenie nowego towaru [...] lub nowego gatunku jakiegoś towaru [...];

2. Wprowadzenie nowej metody produkcji [...] (polegającej) np. na nowym handlowym sposobie postępowania z jakimś towarem;

3. Otwarcie nowego rynku, tj. rynku, na którym dana gałąź przemysłu danego kraju nie była uprzednio wprowadzona [...];

4. Zdobycie nowego źródła surowców lub półfabrykatów [...];

5. Przeprowadzenie nowej organizacji jakiegoś przemysłu..." (Schumpeter 1960, s. 104).

Współcześnie, po okresie przywiązywania wagi przede wszystkim do zmian technologicznych (innowacje produktowe i procesowe), można zauważyć wzrost zainteresowania szerokim, schumpeterowskim rozumieniem innowacji. Do jego koncepcji nawiązują autorzy Podręcznika Oslo wspólnej publikacji Organizacji Współpracy Gospodarczej i Rozwoju (OECD) oraz Europejskiego Urzędu Statystycznego (Eurostat) odnoszącej się do problematyki gromadzenia i wykorzystania danych na temat działalności innowacyjnej w sektorze przedsiębiorstw. W tym opracowaniu wskazano, że „innowacja (innovation) to wdrożenie nowego lub znacząco udoskonalonego produktu (wyrobu lub usługi) lub procesu, nowej metody marketingowej lub nowej metody organizacyjnej w praktyce gospodarczej, organizacji miejsca pracy lub stosunkach z otoczeniem" (OECD 2008, s. 48-49). We wspomnianej publikacji zwraca się uwagę na cztery typy innowacji, odzwierciedlające zmiany w działalności przedsiębiorstw:

$\rightarrow$ innowacje produktowe (nowe lub znacząco udoskonalone produkty i usługi),

$\rightarrow$ innowacje procesowe (znaczące zmiany w metodach produkcji i dostarczania),

$\rightarrow$ innowacje organizacyjne (np. zmiany organizacyjne w zakresie działania, miejsca pracy czy stosunkach firmy z otoczeniem),

$\rightarrow$ innowacje marketingowe (OECD 2008).

Nawiązanie do tego podejścia można znaleźć np. w pracy J.S. Metcalfe'a, który dokonuje klasyfikacji innowacji, uwzględniając stopień nowości. Autor ten zwraca uwagę, że jedynie niewielka liczba innowacji polega na zastąpieniu dotychczas stosowanych produktów lub procesów nowymi rozwiązaniami. Takie usprawnienia nazywa innowacjami 
radykalnymi (radical). Znacznie większa liczba innowacji przyjmuje charakter przyrostowy (incremental), polegający na usprawnieniu dotychczas funkcjonujących rozwiązań (Metcalfe 2000). Przykładowo, pojawienie się telefonów komórkowych można uznać za radykalną zmianę na tle aparatów stacjonarnych, natomiast wprowadzanie nowych modeli smartfonów, o ile nie towarzyszy temu wdrażanie nowej technologii, np. w zakresie przesyłu danych, to zmiana przyrostowa.

W kontekście rozciągania pojęcia "innowacja” na kolejne kategorie warto również zwrócić uwagę na sformułowanie, które pojawiło się stosunkowo niedawno - innowacja społeczna (social innovation). Jest ono wykorzystywane w odniesieniu do nowych pomysłów (produktów, usług), które z jednej strony wychodzą naprzeciw oczekiwaniom społecznym (są bardziej efektywne niż rozwiązania alternatywne), a z drugiej przyczyniają się do poszerzenia możliwości współpracy i tworzenia więzi społecznych (Murray i in. 2010). Innowacje społeczne powstają na styku sektorów: publicznego, prywatnego i tzw. trzeciego przy współudziale osób indywidualnych (BEPA 2011). Podmiotami, które uczestniczą w procesie współtworzenia nowego rozwiązania, mogą być: przedsiębiorstwa, obecni lub przyszli użytkownicy danego dobra, instytucje otoczenia biznesu i finansujące, instytucje naukowe czy władze publiczne różnych szczebli. Szczególnym przypadkiem innowacji społecznych są innowacje miejskie, które rozwiązują określone problemy na obszarach zurbanizowanych i powstają przy współudziale tzw. użytkowników miasta (czyli nie tylko mieszkańców, lecz także np. dojeżdżających do pracy spoza miasta) (Kopyciński 2018). Może to być rozwiązanie o charakterze technologicznym (np. aplikacja do wyszukiwania połączeń komunikacji publicznej) bądź nietechnologicznym (np. stworzenie parku miejskiego).

Globalna konkurencja przyczynia się do skracania cyklu życia produktu, a jednocześnie wykorzystywanie coraz bardziej zaawansowanych technologii sprawia, że wprowadzanie innowacji na rynek jest dla przedsiębiorstw coraz bardziej ryzykowne i kosztowne. Następuje umiędzynarodowienie funkcji przedsiębiorstw, w szczególności tych wymagających dużych nakładów wiedzy ( $w$ tym w zakresie $B+R$ ). Firmy stają się coraz bardziej otwarte na kooperację z innymi podmiotami przy wdrażaniu innowacji. Stopień otwartości zależy zaś od wykorzystywanych technologii, specyfiki sektora i strategii przedsiębiorstwa. Opisane tu procesy zostały określone przez H. Chesbrougha jako open innovation, co może być tłumaczone jako „koncepcja otwartej innowacji", a powstające w wyniku owych działań nowe 
rozwiązanie jako „otwarta innowacja” (Chesbrough i in. 2006, s. 1). Sformułowanie to stworzono na potrzeby sytuacji, w której nowe rozwiązanie powstaje we współpracy z szerokim spektrum aktorów. Jednocześnie prawa do prac, które po wdrożeniu innowacji zostały uznane przez przedsiębiorstwo za zbędne, znajdują nabywców wśród podmiotów zewnętrznych. Te ostatnie z kolei wykorzystująje do własnych celów - wprowadzenia nowych lub udoskonalania dotychczasowych produktów (usług) (OECD 2008a).

W kontekście niniejszych rozważań warto również zapoznać się z trendem nazywanym demokratyzacją innowacji (democratizing innovation). Koncepcję tę szerzej przedstawił w swej pracy z 2005 r. E. von Hippel. Mając na myśli demokratyzację innowacji, zwraca uwagę na wzrastające możliwości prowadzenia działalności innowacyjnej na własne potrzeby przez użytkowników produktów i usług - zarówno podmioty gospodarcze, jak i osoby indywidualne (Hippel 2005). Współcześnie coraz więcej firm, a nawet hobbistów, ma dostęp do nowoczesnych technologii i narzędzi informatycznych, do których uruchomienia wystarczy komputer osobisty. Co więcej, przy niewielkich nakładach pracy mogą być one wykorzystane do powstania nowych produktów i usług spełniających wyrafinowane oczekiwania odbiorców. Możemy więc mówić o demokratyzacji możliwości powstawania innowacji-przyszli użytkownicy zyskują możliwość stworzenia produktów spełniających dokładnie ich oczekiwania (Hippel 2005). Przykładowo: hobbysta dysponujący odpowiednią wiedzą i oprogramowaniem może stworzyć równorzędny względem propozycji wielkiego koncernu system sterowania ruchem w mieście.

Reasumując, można powiedzieć, że w rozważaniach o innowacjach w kategorii zmian technologicznych i nietechnologicznych wprowadzanych przez przedsiębiorstwo towarzyszy też równoległy, niewykluczający pierwszego sposób myślenia, gdzie innowacja powstaje w odpowiedzi na zapotrzebowanie społeczne i jest wynikiem wspólnej pracy wielu podmiotów. W tym drugim ujęciu na dalszy plan schodzi przyporządkowanie takiego rozwiązania do któregoś z typów innowacji według klasyfikacji OECD (technologiczne, nietechnologiczne). Niemniej w obu przypadkach przy wdrażaniu innowacji istotnymi podmiotami są przedsiębiorstwa.

\section{Przedsiębiorczość a innowacyjność}

\section{- punkty wspólne i różnice}

Dotychczasowe rozważania pozwoliły na zdefiniowanie wyrażeń „innowacje" i „innowacyjność", a w tym kontekście również „przedsiębiorczość" oraz 
„przedsiębiorstwo". W tym miejscu warto zastanowić się nad delimitacją tych dwóch kategorii pojęć. „Innowacyjność zależy od przedsiębiorczości w tym sensie, że może być przez nią pobudzana, ale i odwrotnie - może być bodźcem rozwoju przedsiębiorczości jako źródło szans" (Bogdanienko 2017, s. 34). Niekiedy też przedsiębiorczość jest uważana za składową innowacyjności (Bogdanienko 2017). Tak sądzi np. H. Mizgajska (2010), wskazując, że działalność przedsiębiorstw jest uwarunkowana m.in. klimatem przedsiębiorczości. Z kolei Zahra zwraca uwagę, że organizację przedsiębiorczą musi cechować innowacyjność (Bogdanienko 2017).

Odnosząc się do powyższego oraz do wcześniejszych rozważań o przedsiębiorczości, można więc powiedzieć, że omawiane dwie kategorie pojęciowe są wobec siebie współzależne: w niektórych podejściach innowacyjność zależy od przedsiębiorczości, a w innych odwrotnie. Kluczowe wydaje się przy tym rozróżnienie dwóch omawianych na początku rozdziału podejść do przedsiębiorczości: jeśli traktujemy ją stricte $w$ kategoriach zarządzania firmą, to niekoniecznie musi być ona związana z innowacyjnością. Natomiast przedsiębiorczość rozumiana jako znajdowanie i wykorzystywanie szans rynkowych na wprowadzenie nowych produktów (usług) jest jak najbardziej powiązana z innowacyjnością. Jak więc można opisać te związki wobec wielości podejść, z których część została przedstawiona w niniejszym rozdziale?

W tym celu interesujące jest odwołanie się do propozycji T. Bal-Woźniak. Proponuje ona poniższe podejście (Tab. 1).

Tabela 1. Delimitacja pojęć „innowacyjność" i „przedsiębiorczość" - przykład

INNOWACYJNOŚĆ JAKO NARZĘDZIE PRZEDSIĘBIORCZOŚCI (DRUCKER)

\section{ALE}

PRZEDSIĘBIORCZOŚĆ JAKO ZBIÓR ZACHOWAŃ MOŻE WYSTĘPOWAĆ BEZ INNOWACJI

\section{PODCZAS GDY}

INNOWACJA NIE MOŻE ISTNIEĆ BEZ PRZEDSIĘBIORCZOŚCI

\section{A WIĘC}

INNOWACYJNOŚĆ JAKO ZDOLNOŚĆ DO WDRAŻANIA INNOWACJI JEST JEDNYM Z ZASOBÓW PRZEDSIĘBIORCZOŚCI

\section{TO}

ZASOBEM WYMAGAJĄCYM, PO KTÓRY SIĘGA SIĘ, GDY WYCZERPIĄ SIĘ INNE ZASOBY, ŁATWIEJSZE DO ZAGOSPODAROWANIA 
Jak wskazuje T. Bal-Woźniak (2007), przedsiębiorczość jako pewien zbiór zachowań może istnieć bez innowacyjności, ale innowacyjność rozumiana jako zdolność do wdrażania innowacji nie może istnieć bez przedsiębiorczości. Z pewnością jest to istotne spostrzeżenie dotyczące współzależności, przy czym przedsiębiorczość jest tu sformułowaniem dominującym.

\section{Zakończenie}

Jako podsumowanie niniejszego artykułu niech posłużą poniższe zestawienia (Tab. 2 i 3).

Tabela 2. Przedsiębiorczość i przedsiębiorca - rozumienie pojęć

\begin{tabular}{l|l|l} 
WYRAŻeNIE & \multicolumn{1}{c}{$\begin{array}{c}\text { UJĘCIE 1. } \\
\text { ZARZĄDZANIE } \\
\text { PRZEDSIĘBIORSTWEM }\end{array}$} & $\begin{array}{c}\text { UJĘCIE 2. } \\
\text { WPROWADZANIE ZMIAN W PRZEDSIĘBIORSTWIE } \\
\text { (W ASORTYMENCIE PRODUKTóW/UStUG) }\end{array}$ \\
\hline Przedsiębiorczość & $\begin{array}{l}\text { Zdolność i gotowość do } \\
\text { organizowania i rozwijania } \\
\text { działalności przedsiębiorstwa } \\
\text { oraz zarządzania nim w celu } \\
\text { osiągnięcia zysku. }\end{array}$ & $\begin{array}{l}\text { Umiejętność identyfikacji szans i prze- } \\
\text { kuwania ich na innowacje. }\end{array}$ \\
\hline Przedsiębiorca & $\begin{array}{l}\text { Zarządzający - osoba na bie- } \\
\text { żąco kierująca przedsiębior- } \\
\text { stwem, często } \\
\text { właściciel/założyciel, po- } \\
\text { nosząca ryzyko finansowe } \\
\text { funkcjonowania firmy, ale } \\
\text { niekoniecznie odpowiedzialna } \\
\text { za innowacje. }\end{array}$ & $\begin{array}{l}\text { Innowator - osoba posiadająca zdolność } \\
\text { do wprowadzania innowacji. }\end{array}$ \\
\hline
\end{tabular}

Źródło: Opracowanie własne. 
Tabela 3. Innowacja i innowacyjność - rozumienie pojęć

\begin{tabular}{l|l|l}
\multicolumn{1}{c|}{ WYRAŻENIE } & $\begin{array}{c}\text { UJĘCIE 1. INNOWACJA JAKo } \\
\text { PROBLEM PRZEDSĮ̨BIORSTWA }\end{array}$ & \multicolumn{1}{c}{$\begin{array}{c}\text { UJĘCIE 2. INNOWACJA JAKo PROBLEM } \\
\text { SPOŁECZNY }\end{array}$} \\
\hline Innowacja & $\begin{array}{l}\text { Nacisk na efekt w postaci } \\
\text { nowego rozwiązania - różne } \\
\text { klasyfikacje, np. bazujące na } \\
\text { teorii J. Schumpetera podej- } \\
\text { ście OECD: innowacje produk- } \\
\text { towe, procesowe, organizacyj- } \\
\text { ne i marketingowe. }\end{array}$ & $\begin{array}{l}\text { Nacisk na współpracę przy wdrażaniu } \\
\text { - innowacja jako konsekwencja współpra- } \\
\text { ników rozwiązania, przedsiębiorstw, jed- } \\
\text { nostek naukowych, instytucji otoczenia } \\
\text { biznesu, instytucji finansowych i władz } \\
\text { publicznych, będąca spełnieniem zbioro- } \\
\text { wych (kolektywnych) potrzeb. }\end{array}$ \\
\hline Innowacyjność & $\begin{array}{l}\text { Zdolność określonych pod- } \\
\text { miotów (przede wszystkim } \\
\text { przedsiębiorstw) do wdrażania } \\
\text { innowacji. }\end{array}$ & $\begin{array}{l}\text { Zdolność określonych podmiotów } \\
\text { (niekoniecznie przedsiębiorstw) do } \\
\text { wdrażania innowacji. }\end{array}$ \\
\hline
\end{tabular}

Źródło: Opracowanie własne.

Reasumując, możemy powiedzieć, że "przedsiębiorczość" i „innowacyjność" to sformułowania współzależne, z tym że w zależności od podejścia ta pierwsza nie musi być powiązana z wprowadzaniem nowości, podczas gdy innowacyjność jest ściśle związana z przedsiębiorczością (w tym miejscu kwestią wtórną pozostaje, która jest zmienną zależną). 


\section{Bibliografia}

$\rightarrow$ Audretsch, D.B. i in. (2002), The Economics of Science and Technology [w:] "The Journal of Technology Transfer", April 2002, Vol. 27, Issue 2, pp. 155-203.

$\rightarrow$ Bal-Woźniak, T. (2007), Innowacyjność fundamentalnym warunkiem przedsiębiorczości powszechnie opartej na wiedzy. Porównania międzynarodowe [w:] M.G. Woźniak, Nierówności społeczne a wzrost gospodarczy. Gospodarka oparta na wiedzy, Rzeszów: Uniwersytet Rzeszowski.

$\rightarrow$ BEPA (2011), Empowering People, Driving Change. Social Innovation in the European Union, Luxembourg: Publications Office of the European Union.

$\rightarrow$ Bogdanienko, J. (2017), Przedsiębiorczość a innowacyjność - dyskurs terminologiczny, "Marketing i Rynek", nr 11/2017, s. 30-41.

$\rightarrow$ Chesbrough, H., Vanhaverbeke, W., West, J. (2006), Open Innovation: Researching a New Paradigm, Oxford: Oxford University Press.

$\rightarrow$ Von Hippel, E. (2005), Democratizing Innovation, Cambridge, MA/London: The MIT Press.

$\rightarrow$ Kopyciński, P. (2018), City Lab as a Platform for Implementing Urban Innovation. The Role of Companies [w:] K. Wach, M. Maciejewski (red.), (International Entrepreneurship as the Bridge between International Economics and International Business: Conference Proceedings of the 9th ENTRE Conference and 5th AIB-CEE Conference. Cracow: Uniwersytet Ekonomiczny w Krakowie, s. 257-274.

$\rightarrow$ Metcalfe, J.S., (2000), Science, Technology and Innovation Policy in Developing Economies, Paper prepared for the workshop on Enterprise Competitiveness and Public Policies, Barbados 22nd - 25th November 1999.

$\rightarrow$ Mizgajska, H. (2010), Problemy innowacyjności przedsiębiorstw produkcyjnych, "Zeszyty Naukowe Uniwersytetu Ekonomicznego w Poznaniu", nr 131, s. 9-26.

$\rightarrow$ Murray, R., Caulier-Grice, J., Mulgan, G. (2010), The Open Book of Social Innovation, NESTA.

$\rightarrow$ OECD (2008), Podręcznik Oslo, Paris: OECD \& EUROSTAT.

$\rightarrow$ OECD (2008a), Open Innovation in Global Network, Paris. 
$\rightarrow$ Oleksyn, T. (2012), Przedsiębiorczość jako kategoria złożona. Jak ją rozwijać?, „Problemy Zarządzania”, 10/1(2), s. 8-25.

$\rightarrow$ Schumpeter, J. (1960), Teorie rozwoju gospodarczego, Warszawa: PWN.

$\rightarrow$ Torfing, J. (2016), Collaborative Innovation in the Public Sector, Washington DC: Georgetown University Press.

$\rightarrow$ World Bank \& European Network of Living Labs (2014), Citizen-Driven Innovation: A Guidebook for City Mayors and Public Administrators, Brussels: World Bank \& European Network of Living Labs. 


\section{Netografia}

$\rightarrow$ Business Dictionary, www.businessdictionary.com (dostęp: 15.11.2018). 